\title{
Investigating the oil effect on the politicking in the 19th August, 1953 Coup d'état
}

\author{
Seid Mohamad Reza Mahmodpanahi ${ }^{1,{ }^{*}}$, Sosan Shokriaghkand ${ }^{2}$ \\ ${ }^{1}$ Assistant professor, Department of History, Payame Noor University, PO BOX 19395 - 3697, \\ Tehran, IRAN \\ ${ }^{2} \mathrm{MA}$, Department of History (Iran Islamic period), Shahid Beheshti University, Tehran, Iran \\ Dr.mahmoudpanahi@gmail.com
}

Keywords: Oil and energy, the 19th August, 1953 Coup d'état, England, America, Mosadegh, Mohamad Reza Shah

\begin{abstract}
The strategic situation of Iran has always drawn the attention of foreign powers including England, Russia and America and these powers have always attempted to utilize this situation for reaching their own interests in the Middle East. Discovery of large oil reserves in Iran intensified the competition of foreign powers. This research seeks to respond the question of how foreign powers intervened with the 19th August, 1953 Coup d'état. In the 19th August, 1953 Coup d'état, the Americans and English having after made sure that they could not seize the Iranian oil through political channels, they decide to launch a Coup d'état. With the victory of the $19^{\text {th }}$ August, 1953 Coup d'état and subversion of the Dr. Mosadegh's government, the United States and Britain consolidated their own dominate in Iran via returning Mohamad Reza Shah and the oil reserves were once again made available to foreign powers. This research via applying comparative descriptive methodology is based on documents and evidence. Findings of the research and examination of the 19th August, 1953 Coup d'état demonstrate that the significance of oil and energy and fear of the spread of the Oil National Movement to other oil producing countries and compromise of oil resources as well resulted in intervention by cross regional foreign powers like England, America with respect to the 19th August, 1953 Coup d'état.
\end{abstract}

\section{Introduction}

\section{Joint plan approved}

The very idea of overturning the Mosadegh's government through Coup was for the first time raised by the English state and the former oil company. After the approval of the law of nationalization of the oil industry and the government's decision to divest the Iranian and English oil companies, the labor English government presided over by Clement Ethel investigated the plan of immediate occupation of the Abadan's installations. Then, its execution plan called the "Buccaneer" operations was approved by the board of government. Subsequently, several military units were deployed in Libya, but the implementation of the said plan stopped with the opposition by the United States.

Later, after the transfer of power from the labor government to a conservative government, the Churchill's cabinet examined the plan for the overthrow of the state through coup and following the severance of all relations between then English and Iranian government by the autumn 1952, the British Conservative government followed the coup plan in Iran seriously and finally with the agreement of the new government in America (Eisenhower's government), the plan went ahead [1]. The 1952 autumn and winter were critical periods during which the English and Americans in agreement with each other engaged in a outlining a map for an undercover operation against the Mosadegh's government [2]. On this basis (on November, 1952), the MI6 chief Woodhouse went to London to meet with Eden, the English Conservative foreign minister. In a session held with the presence of Eden, it was believed that the whole plan could be finished in the same meeting; however Aden mentioned that such an operation at this level could not be successful without the backing of the United States. 
For this purpose, in the mid-November 1952, Woodhouse arrived in Washington to engage in talks with CIA officials surrounding the Coup plan. In this trip, Woodhouse placed emphasis on then risk of a Coup on the part of the Toude (People) party so to attract the attention of the CIA officials. The English foreign minister, Eden had become successful in this time to convince Americans that there was a third solution between Nationalism and Communism. Up to this time, Americans thought that if Mosadegh fails, Communism will replace him. In this stage, both Eden and Woodhouse had managed to sell this theory to Americans that lack of support for the Mosadegh's government would not result in the arrival of Communism, rather one can bring to office a government which both sup[presses Nationalism and Communism. The plan presented to American officials by Woodhouse included a Coup based on relations with chiefs of the South Tribes and the equipped Organization of Rashidian Brothers in Tehran. According to the Woodlouse's plan, a scheduled riot was aimed to take place throughout the country, later Mosadegh and his ministers would be arrested by British agents and major and critical cities be occupied and a prime minister agreed by the English and Americans would take office [3].

Woodhouse engaged in talks with American officials at the foreign secretary, In the end, he was told that the Truman's state would not be willing to agree with his plan, however the next president elect, Eisenhower would [4]. Concurrently, with the travel of Woodhouse to Washington in November, 1952, Roosevelt, the chief of CIA operations in the Middle East upon returning from Tehran stopped din London and talked with some political officials in England. In this contact, the English raised the plan of coup for the overturning of the Mosadegh's government for the first time.

Roosevelt's negotiation with English political officials in London coincided with Woodlouse's talks with American officials in Washington' this coincidence was effective ion joint plans, because the same plan Woodhouse had presented in Washington, had been introduced to Roosevelt in London. This issue caused Roosevelt to return to Washington with the same thoughts and theories (1997). Upon returning from London, Roosevelt reported his own negotiations with the English to Allen Dallas, who was the then CIA deputy. In December, 1952, Eisenhower, from the Republican Party won the presidential elections but the ceremony of transition of power took place in January 1953. During those several weeks, Roosevelt and Walkman Dallas conducted negotiations and undercover examination regarding the English plan and also preparing another plan in collaboration with the English for the overthrow of the Mosadegh's government without the notification of Truman and Acheson, the then foreign secretary (1989).

In early February, 1953, the English government's charge d'affaires and those of the Intelligence Service went to Washington in order for engagement in talks with new American officials in connection with the joint plan. In the third secession held in February 1953, they agreed about the conduct of the joint plan [3]. England had arranged the Coup plan under the title of "Boot operations" and the United States applied the "Bedamen Project" which had been utilized against regional Communism parties in 1948 and thereafter the two operations were integrated and the "Ajax operation" was made available [5]. This plan included the Iranian Shah, Winston Churchill, Anthony Eden and Eisenhower, john Foster Dallas and the CIA. Roosevelt was selected as the chief of the operation. Though he could not speak Persian and lacked knowledge about Iran, he did have some qualifications and competencies. He did have some knowledge about oil business to some extent and in the late 1940s he had been appointed as the member of the board of influential advisers for acquiring oil franchise in Iran. Besides this, he could talk to the Iranian Shah under his own name. To increase his own reliability, Roosevelt met with Churchill in the direction of his own mission and received full support from him. Prior to leaving Washington he was given some intelligence about Mosadegh including " he is an old villager man with some illusions responsibility and reality; someone who have prejudices about all the problems from his sensational point of view" [6].

Thereafter, the CIA was authorized to plan for the Coup and after a while, a million dollar was granted to the CIA basis in Tehran to spend it for the subversion of Mosadegh. On 28 April, 1953, CIA prepared a primary report that would allow for the conduct of a coup and the most appropriate appointee for the succession $\mathrm{f}$ Mosadegh was Major General Zahedi [7]. If the masterly measures 
by the English with plans outlined by Roosevelt regarding Mid-East were not made parallel, they could not be successful. Little after the April 25, 1953, the date on which the two governments had agreed regarding Zahedi as the successor, Roosevelt was give green light to go ahead and coordinate all the relevant details [2].

After that, studies by the CIA and Intelligence service commenced. Donald Wilber from CIA and Norman Derby from the Intelligence Service were charged with study and design the primary plan of Coup. Studies started in Nicosia, Cyprus where the English Intelligence Service had been transferred there from Tehran having after the Mosadegh's government had ceased ties with England. The very initial plan for coup was arranged in 6 stages: first, the CIA basis in Tehran would perform large scale propaganda for stirring and maximizing anti Mosadegh sensations. Second, Zahedi would create a military offshoot along with coordinating a number of army officers financed with the CIA and the Intelligence Service. Third, the U.S. ambassador would start efforts for drawing the satisfaction and cooperation of Shah. Fourth, the Rashidian brothers who were operators of political and Intelligence Service espionage network would attempt to buy a number of representatives and attract their votes so that they would be able to acquire enough votes for the overturning of Mosadegh. Fifth, Jalali and Keivani (Boscov brothers), of active members of the political action network of the CIA along with Rashidian brothers and a number of religious influential and Market leaders, would organize thousands of protesters on the morning of "Coup day" so that they would sit-in in the parliament and convict Mosadegh as fighting religion and taking Iran towards decline. This would pave the way for the removal of Mosadegh by the Parliament through Quasi channels; but it had been predicted that if the coup reaches nowhere through Quasi channels, the coup military offshoot led by Zahedi would act and oust Mosadegh forcibly.

When the initial plan of the Coup was arranged by Wilber and Derby, $t$ was reviewed and inspected by other American and English officials and finally, its final version was formulated on June 27, 1953 and approved by governments of England and America in August. CIA, after the primary confirmation of the operation in June formed two groups in Washington for the provision of the Coup. John Waller was charged as responsible for these groups and would present his reports to the CIA [7].

The Coup plan had two major parts:

1. Creation of turbulence and chaos in order for destabilization of the government and implementation of a conventional military coup for the subversion of the government; Wilber was personably charged with the arrangement of "Psychological war and antiMosadegh propaganda". He was charged with "white" and "black" propaganda. Propaganda of white kind was destructive intelligence but real and relevant while the black propaganda included presentation of intelligence which was unreal and misleading. CIA and MI6 insisted on the Communism threats, but simultaneously, they injected the regular financial trend-11000 dollars in each week- for around 20-30 parliament representatives and for more than 20 newspapers which released and translated papers regularly, to chiefs of Bakhtiari tribes leaders which had waged riots in February, 1952; to an "anonymous terrorist groups":, to Fedayan and due to their "direct engagement with Mosadegh and this allies", to Arya, and Zahmatkeshan parties and through Ayatollah Behbahani as well as to hooligans and felons. These mobs were greater than the right handed small parties. The money in circulation in 1953 was made known as Behbahani dollars. The most serious action for destabilization occurred in May through which Baghaee's advocates with active participation of General Mahmoud Afshar Toos abducted chief of police station, persecuted him and killed at last.

2. The military part of the coup was led by "Carol" who was heavily relied on Shah. He was supposed to give a "Quasi legal cover" to then coup. The Shah, also was then sole reliable and valid face among the army officers. Major General Zahedi was a material person with some Bluff tendencies. To attract the attention of Shah, the CIA and MI6 made use of some 
new ambassadors who were [6]. Ashraf Pahlavi, on $3^{\text {rd }}$ July arrived in Mehrabad airport on board of an Air France Plane under a passport called" Miss. Shafigh". The arrival of Ashraf was unanticipated such that none of the courtiers went to welcome her at the airport (Ittila'at newspaper, year 28, No. 8150, dated July 4, 1953, Sat. p. 1). Her trip to Tehran was revealed and instigated the sensitivity of the state's advocates and for the same reason, he left the country speedily; meanwhile to the same time, she managed to perform her coup related mission [7].

A week after that, General Norman Shcwartskf who was the commander of Shah in person. The arrangement of this meeting was provided by Rashidian brothers [4]. The CIA also dispatched Roosevelt to Tehran. He managed to convince the Shah that Washington along with financial support would seek a valid oil agreement as well as guarantying of support for the Reign so that the coup would go through [6]. The Zahedi's group which had obtained the Shah's cooperation could step in the direction of the Coup. The decree for the ouster of Mosadegh and selection of Zahedi to the position of prim ministry was issued and signed [4]. At this time, Mosadegh was reported of the fact that some people, inside the parliament were busy plotting against him. In here, Dr. Mosadegh, in order to prevent the activity of the state's opponents decided to hold a referendum the dissolution of the $17^{\text {th }}$ Parliament. Elections were held on $12^{\text {th }}$ and $18^{\text {th }}$ August and majority of people gave vote to the dissolution of the Parliament. The National Council Parliament was thus far dissolved/ IN concurrence with the dissolution of the Parliament, the Shah and his wife flied to the Caspian Coasts upon a previous appointment [3].

\section{Failed Coup}

Colonel Nasiri was supposed to take the decree of Mosadegh's ouster to him and arrest him on $23^{\text {rd }}$ and $24^{\text {th }}$ nights. However, this plan was delayed for one night. The Mosadegh's government was notified of the coup and did some things to prevent it [7].

Colonel Daftari states about one of the bodyguards of the Dr. Mosadegh's house:" As routine, we wanted to take some rest after determining some watches in the mid-night. At this time, it was little after 12 O'clock when some tumult rose of out of the Dr.'s house. I immediately came out and observed that by the intersection, four trucks of soldiers along with two Jeeps and armored vehicles were standing. Under this condition, I saw that Colonel Nasiri, the commander of Royal Guard was standing in front of the prime minister's house, stating" I have brought about a letter fir the prime minister and it has to be delivered to him immediately". He was showing an envelope in his hands. On the envelope, it was reading: "Your excellency, Dr. Prime minister, Mohamad Mosaadegh". Colonel Nasiri insisted that he had to deliver the letter to the prime minister by himself but this was not made possible and another one took the letter $t$ the prime minister and after a while, it became clear that the subject of the letter was fake and it was a pretext and the existence of soldiers and the armored vehicles close to the prime minister's house was for another purpose.

At this time, the officers, at the Heshmat Allah intersection and on street Kakh arrested Colonel Nasiri at first and the others((Ittila'at newspaper, year 28, No. 8150, dated August 4, 1953, Sat. p. 1).Until the morning of 16th August, most officers participating in the conspiracy of coup were arrested a d the Royal Guard soldiers were also disarmed and hence, as a result of awareness of the Toude party military organization, this time again the plan of Coup became futile. Mohamad Reza Shah, having notified of the affair who was seeing a scandal due to the failure of the Coup fled to Baghdad on board of his own plane. After the $16^{\text {th }}$ august Coup failure and escape of the Shah, Major General Zahedi, the prime minister of the coup remained in Tehran and took refuge to the U.S. embassy covertly so that he would be this time around able to fulfill the plan. On august $16^{\text {th }}$, when the news of the coup failure and the escape of Shah were notified to the public, people staged rallied in emotions and participated in public demonstrations. In Tehran, the most immense and largest demonstrations were held against the Royal Kingdom [8]. 


\section{The 19th August, 1953 Coup d'état}

Immediately, after the Nasiri's failure, some people in the CIA and MI6 conclude that the whole Coup was failing. Washington ordered Roosevelt to leave Iran [9]. Some plans for the exit of Roosevelt, Zahedi and a number of the key practitioners were prepared so that they would be able to exit from Iran via a plane belonging to America [4]. Robert Mc Clore was still thinking of t6the only hope for the execution of the Coup, i.e. General Ryahi. Roosevelt maintained that the simple quasi legal part of the coup had failed. For them, the Coup's central network and its military structure was to large extent intact and via performing some initiatives, the possibility of executing the initial plan was made available [9]. Zahedi was taken to a safe CIA basis and he hid there until the late hours of the Mosadegh's subversion operation. Thus, the Roosevelt group did some various but coordinated actions for the implementation of the coup. The first action was the revelation of the Shah's decision to outs Mosadegh and selection of Zahedi to the post of prime minister; something that Mosadegh had not announced this to the public. CIA officers, on $16^{\text {th }}$ August prepared some versions of the Shah's decree and disseminated them across Tehran [4].

The second stage of the plan was the action for attracting the support of the military men from the Coup. After the distribution of the Decree's version, some measures were adopted for supporting the military men in barracks outside of Tehran. A declaration was disseminated and distributed through which the army had been demanded to support the Shah. The last stage of the Roosevelt's plan was dragging the mobs and hooligans to the streets in order for attacking state offices and creating fear and horror among people. Rashidian brothers who were considered Britain agents were charged with this [3]. During three days from 16thn to $19^{\text {th }}$, August, street demonstrations of various parties and groups continued. People would overturn the statues of Reza Shah and Mohamad Reza Shah, lower photos of Shah and the Royal courtiers and would busy substituting the names of the streets. The great American ambassador, Henderson who administered Coup from a foreign point of view and wanted to arrive in Tehran after the fall of Dr. Mosadegh, arrived in Tehran on $17^{\text {th }}$ august hastily and met with Dr. Mosadegh immediately. According the Paris Radio, he notified Dr. Mosadegh in this meeting that:" The United States will strongly prevent his governance and ordered Mosadegh to resign. However, Dr. Mosadegh got Henderson out of his house with a strong accent and Said that he would cut off all ties with America" [8].

Prior to meeting with Henderson, Mosadegh intended to be accepted to form a Royal Council and his advisors had prepared a plan in this regard. However, after talks with Henderson, Mosadegh changed view and decided to fulfill the job and performed the removal of Mohamad Reza Shah and the decline of Pahlavi Reign through referendum. However, he was still dubious regarding change of regime to republican from kingdom. However, he had this readiness to entrust the destination of the nation or the hands of the people themselves. However, Stating demonstrations of the Toude parties and their rallies on the evening, $18^{\text {th }}$ august was one of the weak factors of Mosadegh and his followers. CIA agents managed to create turbulence in the city via creating fake demonstrations [7]. Afternoon, $18^{\text {th }}$ august, when the military government announced the end of the popular demonstrations, Mahmoud Mesgar, one of the directors of the films Shahre No (new city) and Icy Ramazan who was famous among people poured to the streets of Lale Zar and Nader along with some of his followers and with the help of groups of army sergeants wearing personal clothes staged "Love of Shah" demonstrations. These demonstrations continued in the morning of the $19^{\text {th }}$ august in a disperse manner and was led by Shaban Bimokh. Dr. Mosadegh, upon relying on commanders of the army units residing in Tehran and following his own policy of lack of decisiveness and cooperation did not leave the scene even after the eventuality. For this, Dr. Mosadegh, despite the request a $d$ insistence of his friends to announce Coup via radio and asking for help from the people of this country rejected so that he can action that could have motivated large scale demonstrations across the country and thereby lead to the failure of the coup [8].The chief boss of the national police department, brigadier Mohamad Daftari was among the relatives of Mosadegh who was accompanied with coup followers and on the $19^{\text {th }}$ august, he encouraged thee police forces to join demonstrations, Thus, the rebel force attacked major offices comfortably a d captured them one after the other [7]. 
Zahedi came out of the safe haven to seize the affairs and in a telegraph invited the Shah to immediately return to the country. One of the military units advocating Zahedi supported Zahedi via distributing support for him through radio. Finally, at 5 O'clock, tanks launched an offense into the prime minister. After an intense engagement between offenders and guards of the Mosadegh's house, as many as 300 people lost their lives [3]. Mosadegh went off his home and hid; however the next day he surrendered himself to the coup plotters [7].

5. Signature of oil contract and formation of oil consortium,

With the suppression of the Iran's National Movement, an appropriate setting was prepared for the colonial ends of America and England. The most important duty of the obedient state of Zahedi was to resolve the oil issue based on the American and English theories. Under such circumstances, American and English colonialist, in order to seize the Iranian oil reserves and upon the recommendations of the American state formed a consortium of American oil companies, French and Holland oil companies and those England [1]. The Iran's contract with this Consortium was signed on $19^{\text {th }}$ august, 1954 for a period of 25 years with the possibility of extension for another five year old period by the Ali Amini, the then Iranian Financial minister and Howard Pitch on the behalf of the Consortium in Tehran. This contract was made famous as the Amini-Pitch Contract. The opponents of this contract believed that this would violate the Nationalization Law of Oil [10]. Economically speaking, Iran became the exporter of oil to America and the Western World and the issue of Economic independence was forgotten [11].

6. The Soviet's reaction against the in the 19th August Coup

Though the 19th August, coup happened during the Cold War and this war overshadowed the oil crisis between England and Iran and the American officials announced the rational justification of acting towards the coup as the west's worry over Iran being overwhelmed into the Communism claws, it became clear later that the coup was a product of an agreement and a hidden coalition between Communism and imperialism [5]. Prior to the Coup, Soviet's media were speaking of a possible military Coup led by the United States and after the success of the coup and arrest of Dr. Mosadegh Moscow protested America strongly but did do nothing [12].

\section{Conclusion}

With the failure of English policies against the Oil Industry Nationalization Movement, the Charge D'affaires of the English government and the Intelligence Service went to Washington and agreed with them over the joint operation plan called Ajax Project. Roosevelt was chosen as the chief of the Coup operation. After the failure of the $16^{\text {th }}$ august coup, he managed to organize another coup. On $19^{\text {th }}$ august, 1953, the English and American coup was victorious and the new regime out of the coup led by Zahedi returned to the country. The Coup regime struck an agreement with the International Oil Cartel. The main goal of America and glands of launching the coup was fear of spreading of the Oil Nationalization Movement to the regional countries and compromise of their oil interest. Thus, they thought of new approaches to deal with this political affair.

\section{References}

[1] G. R. Nejati, Oil Industry Nationalization Movement and the 19th august coup, $6^{\text {th }}$ edition. Tehran: Enteshar press company, 1989.

[2] J. Bill and W. Roger Lewis, Mosadegh, Oil and Iranian Nationalism, Tr. Abdul Reza Hooshang Mahdavi, Kave Bayat, third edition. Tehran: Goftar publication, 1992.

[3] E. Eghbal, Role of England in the $19^{\text {th }}$ august 1953, first edition. Tehran: Ittila'at publication, 1997. 
[4] M. Gazirosky, America's foreign policy and the Shah: a submissive government in Iran. Tehran: Resa publication, 1998.

[5] A. Bigdeli, Oil and coup. monthly quarterly and political history of Iran Moaser, vol. 3, pp. 40-45, 2002

[6] Y. Abrahamian, History of Modern Iran. Tr. Ebrahim Fatahi, Second edition. Tehran: Nei publication, 2010.

[7] D. Rahmanian, Iran between two coups, (history of political, social, economic, cultural developments from the fall of Qajar to the 1954 coup, first edition. Tehran: SAMT publication, 2012.

[8] M. Jami, The past is the way forward, History of Iran in the interval between two coups, sixth edition. Tehran: Ghoghnos publication, 1999.

[9] Y. Abrahamian, $19^{\text {th }}$ august Coup, CIA and roots of relations between Iran and United States in the modern era, Tr. by Ebrahim Fatahi. Tehran: Nei publication, 2013.

[10] A. R. Hooshang Mahdavi, History of foreign relations of Iran after the Second World War up until the Fall of Pahlavi regime, first edition. Tehran: Moalef publication, 1989.

[11] P. Avari, Contemporary history of Iran: from the establishment of the Pahlavi era to the $1^{\text {9th }}$ august 1953 coup, Tr. Mohamad Rafiei Mehrabadi, Ataeepress institute, vol. 3, pp. 5-6, 1984.

[12] N. Irani, Role of democracy in Iran and 12 more papers, First edition. Tehran: Daneshgahi Center publication, 1992. 